\title{
Quem matou Saul?
}

\section{Luiz José Dietrich*}

\section{Resumo}

A revisão da chamada "arqueologia Bíblica" pela "nova arqueologia" tornou necessária uma nova narrativa histórica sobre os primórdios de Israel, uma narrativa coerente com a exegese crítica, a leitura feminista e com o arcabouço arqueológico atual. Buscando contribuir nesta direção, este artigo considera a sugestão recente de que a unidade política liderada por Saul teria causado a incursão de Sheshonq/Sisac nas terras de Israel, e de que este faraó teria matado Saul no final do séc. X a.C. (FINKELSTEIN, 2013, p. 38-44 e 59-61; seguido por KAEFER, 2014, p. 160; 2015, p. 891-892; e 2015b, p. 41-42). Este artigo discorda desta proposta e apresenta argumentos defendendo que quem matou Saul foram os filisteus, uns 20 anos antes da invasão de Sheshonq.

Palavras chave: Arqueologia. Saul. Filisteus. Sheshonq/Sisac. Davi.

\section{Who killed Saul?}

\section{Abstract}

The revision of the so-called "Biblical archaeology" by the "new archaeology" brought the necessity of a new historical narrative about the early days of Israel, a narrative based on the critical exegesis, feminist readings and actual archaeology framework. Expecting to contribute in this direction, this article considers a recent suggestion that the political unity leaded by Saul would have caused sheshonq/Shishac's incursion into the lands of Israel and that this pharaoh would have killed Saul at the end of the 10th century BC. (FINKELSTEIN, 2013, p. 38-44 and 59-61; followed by KAEFER, 2014, p. $160 ; 2015$, p. $891-892$ and 2015b, p. 41-42). This article disagrees with this proposal and presents arguments arguing that who killed Saul were the Philistines, around 20 years before Sheshonq's invasion.

Keywords: Archaeology. Saul. Philistines. Sheshonq/Shishac. David.

\footnotetext{
* Professor Adjunto do Programa de Pós-Graduação em Teologia da Pontifícia Universidade Católica do Paraná. Email: luiz.dietrich@pucpr.br.
} 


\section{¿Quien mató Saul?}

\section{Resumen}

La revisión de la llamada "arqueología bíblica" por la "nueva arqueología" hace necesaria una nueva narrativa histórica sobre los primeros días de Israel, una narrativa basada en la exégesis crítica, la lectura feminista y el actual esbozo arqueológico. Buscando contribuir en esta dirección, este artículo considera una sugerencia reciente de que la unidad política liderada por Saúl habría causado la incursión de Sheshonq/Sisac en las tierras de Israel y que este faraón habría matado a Saúl a finales del siglo X a.C. (FINKELSTEIN, 2013, p. 38-44 y 59-61; seguido de KAEFER, 2014, p. 160; 2015, p. 891-892 y 2015b, p. 41-42) Este artículo no está de acuerdo con esta propuesta y presenta argumentos defendiendo que Saúl fue muerto por los filisteos, unos 20 años antes de la invasión de Sheshonq.

Palabras clave: Arqueología. Saúl. Filisteos. Sheshonq/Sisac. David.

\section{História de Israel: os desafios atuais}

O campo dos estudos do Antigo Israel é fortemente impactado pelo trabalho da nova arqueologia na revisão da chamada "arqueologia Bíblica" (FINKELSTEIN; SILBERMAN, 2003, p. 35-41). No estudo do Pentateuco há o questionamento da teoria documentária (SKA, 2016, p. 24-43), especialmente impulsionado pela falta de evidências arqueológicas para sustentar a existência do império davídico-salomônico; e pela epigrafia que aponta os séculos VIII e VII a.C. como o momento do surgimento dos primeiros escritos significativos na elaboração da Bíblia Hebraica (FINKELSTEIN; SILBERMAN, 2003, p. 40; SCHNIEDEWIND, 2011; CARR, 2011, p. 304-338.). Junte-se a isso a constatação de que a concepção politeísta predominava no Israel pré-exílico, com muitos testemunhos que revelam o culto a uma grande diversidade de Deuses e Deusas, em que Javé e Elohim eram cultuados tanto em Israel, no norte, como em Judá, no sul (SMITH, 1999; DAY, 2000; REIMER, 2009, p. 21-52; ANDERSON, 2015).

$\mathrm{Na}$ atualidade somos desafiadas e desafiados a encontrar novas narrativas para contar a história de Israel, a história das religiões de Israel, do processo de instituição do monoteísmo, e novas explicações a respeito de quando e como foram escritos o Pentateuco e a própria Bíblia. O desafio inclui a necessidade de buscar uma nova narrativa histórica sobre os primórdios de Israel, que seja coerente com os estudos críticos da Bíblia, com as contribuições da exegese feminista e especialmente com a nova arqueologia.

Os indícios arqueológicos revisados e ou levantados pela arqueologia nas últimas décadas revelam um início bem mais modesto para Israel e 
principalmente para Judá. A existência de um reino unido nos tempos de Davi e Salomão, como descrito em 2Sm - 1Rs, é praticamente descartada (FINKELSTEIN; SILBERMAN, 2003, p. 174-203). Com isso também se desmonta o tradicional discurso linear que apresentava a história de Israel em períodos sequenciados - tribos - monarquia unida - divisão da monarquia - que se sucediam na história. E, como escrito acima, a tradicional teoria documentária, que orientou o estudo do Pentateuco por muitas décadas, já há tempos questionada, no mínimo precisa ser revista ${ }^{1}$.

A questão de fundo é a história de Israel. O debate sobre a história de Israel e até mesmo sobre a possibilidade de se escrever uma história em Israel já se desenrola a mais de duas décadas². E ainda há muito por fazer. A pesquisa bíblica brasileira também busca contribuir na tarefa de apresentar uma nova compreensão da História de Israel e da própria Bíblia (ZABATIERO, 2013; KAEFER, 2015; REIMER, 2017). Esse artigo pretende ser uma modesta contribuição nesta caminhada, refletindo especialmente sobre Saul, como o chefe de uma unidade política na região montanhosa central de Israel, nos primórdios de Israel. Foi motivado pelo fato de vários autores terem apresentado a sugestão de que esta unidade política teria causado a incursão do Faraó Sheshonq/Sisac nas terras altas de Israel e que este faraó teria matado Saul no final do séc. X a.C. (FINKELSTEIN, 2013, p. 38-44 e 59-61; seguido por KAEFER, 2014, p. 160 e 2015, p. 41-42). Este artigo discorda desta proposta e apresenta argumentos defendendo que quem matou Saul foram os filisteus, concordando nesse ponto com a narrativa bíblica. Essa opinião é compartilhada, embora com datações variadas, por muitos autores (LIVERANI, 2008, p. 126; MILLER; HAYES, 2006, p. 143; GRABBE, 2007, p. 112; LIPINSKI, 2018, p. 51, e outros).

A aceitação de que Saul teria sido morto pelo faraó Sheshonq traz mais problemas do que soluções. Aceitando-se esta hipótese o reinado de Saul teria que ter ocorrido "entre os anos 950 e 920" (KAEFER, 2015, p. 42) quase que simultaneamente ao reinado de Davi, Salomão, Roboão e Jeroboão I. E a cronologia destes reinados ficaria totalmente embolada e apresentando muitas dificuldades. E isto mesmo aceitando que a linearidade

Uma forma atualizada da teoria é apresentada por Joel S. Baden, na obra: The composition of the Pentateuch. Renewing the documentary Hypothesis. (The Anchor Yale Bible Reference Library). New Haven/London: Yale University Press, 2012.

2 Para a história da pesquisa ver, DA SILVA, A. J. A história de Israel na pesquisa atual. In: FARIA, J. de F. (Org.) História de Israel e as pesquisas mais recentes. Petrópolis: Vozes, 2003, p. 41-87; e ZABATIERO, 2013, p. 31-53. 
sucessória entre estes reinados é fictícia, e que existem até agora muito poucos dados arqueológicos extra bíblicos referentes a estes reis e às épocas em que viveram. Pois, de Saul não temos nada, a não ser hipóteses que o ligam a um conjunto de fortificações em Gabaá-Gabaon (FINKELSTEIN, 2015, p. 59-65) coração fortificado da tribo de Benjamin (HALPERN, 2017, p. 342). Aceitase a historicidade de Davi e do seu reino a partir menção "casa de Davi" na Estela de Dan (BIRAN; NAVEH, 1993; DEVER, 2001, p. 128-129; CLINE, 2009, p. 61) ${ }^{3}$, embora não tenhamos dados diretos sobre ele. De Salomão nada foi encontrado. De Jeroboão I, tampouco sabemos algo, mas a cronologia de seu reinado é aceita pela moderna arqueologia: após apresentar uma lista dos reis de Israel norte, iniciando com o reinado de Jeroboão I em 931-909 a.C., Finkelstein afirma: "Não vejo razão para duvidar dos nomes, ordem e datas desses reis" (2015, p. 86). Deste modo, mesmo Finkelstein defendendo que a campanha de Sheshonq possa ter acontecido "em qualquer tempo da metade do século X a.C." (2015, p. 61)4 , ou "segunda metade do século X a.C. (2015, p. 73), o espaço de tempo seria muito pequeno para nele alocar os reinados de Saul, Davi, Salomão e Jeroboão $I^{5}$.

Atualmente a história de Israel é apresentada de várias maneiras. Revela grande variedade de matizes. Há os que seguem mantendo a crença e o discurso de que a narrativa bíblica é um relato fiel, sem erros e imprecisões, de tudo o que aconteceu na história de Israel (fundamentalistas). Há os estudiosos que aceitam a estrutura básica da narrativa bíblica como a principal referência para a história de Israel, interpretando os achados arqueológicos de forma a confirmar a maior parte da narrativa bíblica. Estes são chamados de maximalistas (Por exemplo: PROVAN; LONG; LONGMAN III, 2016). E há também os pesquisadores chamados minimalistas, como Niels Peter Lemche, para quem o "AT não é uma fonte primária da história do Antigo Israel, pois

3 Embora ainda se discuta se tal expressão é uma referência à dinastia de Davi, ou é um topônimo para a região de Jerusalém. Ver, por exemplo, ATHAS, G. The Tel Dan

Inscription: A Reappraisal and a New Interpretation. London/New York: T\&T Clark International, $2^{\mathrm{a}}$ impressão, 2005, especialmente p. 217-226.

4 No texto do original inglês: "any time in the mid - to late tenth century B.C.E" (FINKELSTEIN, 2013, p. 41). Com base em diversos estudos Lipinski diz que a afirmação de Finkelstein, "pode ser seguramente descartada" e crava o ano de 924 a.C. como a data da principal campanha de Sheshonq I na Palestina (LIPINSKI, 2018, p. 58).

5 Provavelmente por isso, em maio de 2019, quando esteve na Universidade Metodista de São Paulo dando o curso de extensão: Repensando Israel e Judá, em conversa particular o Professor Israel Finkelstein admitiu não mais crer na hipótese de que Saul fora morto por Sheshonq. 
não está preservado em uma condição que fisicamente remonta ao tempo descrito em sua literatura histórica” (1998, p. 24). Estes não aceitam a Bíblia como um documento referencial, com valor histórico, e tendem a descrever a história de Israel e da Bíblia considerando somente os dados da moderna arqueologia. Entre estes últimos, não são poucos os que afirmam que dada a escassez de bases arqueológicos para o período pré-exílico, é impossível escrever uma história que abarque esse período de Israel.

Embora os chamados minimalistas quase descartem os textos bíblicos para compreender a história de Israel, é preciso reconhecer que, como os materiais encontrados num tel de terra ${ }^{6}$ pelos arqueólogos, os textos bíblicos, recentes ou antigos, são uma espécie de tel de textos, também frutos da história de Israel, e igualmente neles podem ser encontradas marcas dessa história. O diálogo e a cooperação entre as várias ciências, com especial destaque para a exegese crítica, a moderna arqueologia e a epigrafia, parece-nos fundamental para que sejamos capazes de dar conta dos desafios no campo da história de Israel e da Bíblia (assim também LIVERANI, 2008, p. 14).

Um uso não "secularista", mas "laico ou pós-secular" (ZABATIERO, 2013 , p. 42), equilibrado e crítico, tanto dos textos bíblicos, "o livro de papel", quanto do chamado "livro de pedra", (as informações fornecidas pelas escavações arqueológicas, geralmente são retiradas do estudos arquiteturais, dos objetos de pedra, cerâmicas, metais, e outros materiais - atualmente crescem em importância as amostras orgânicas - encontrados nas ruínas antigas), parece ser o caminho mais frutuoso para a reconstrução de uma história de Israel. Este artigo pretende fazer uma incursão nesta trilha.

\section{O contexto em que nasce a organização política de Saul}

A situação que se estabeleceu principalmente nos vales do norte da Palestina, com reconstrução das cidades, a integração dos povos do mar na reorganização e reestruturação da sociedade, é chamada de "Nova Canaã" pelo arqueólogo Israel Finkelstein. Este autor sugere esta denominação porque a recuperação do sistema de assentamentos nos vales do norte "conduziu todas as principais localidades a uma prosperidade completa" no final do século XI e início do século X (FINKELSTEIN, 2015, p. 46.). Ele cita especialmente as cidades de Megido; Kineret, que substituiu a cidade de Hasor no norte do

Tel na arqueologia é uma colina ou um monte artificial formado por diversas camadas de restos de ocupação e construções humanas que foram sobrepostas umas às outras ao longo da história. 
mar da Galiléia; Tel Keisan (Acsaf), próxima de Aco, na Planície costeira; Tel Jocnean e Tel Rehov no vale de Jezrael. Tel Rehov inclusive funcionou como um centro que dominou os vales de Bet Shean e a parte oriental da planície de Jezrael. A parte ocidental era controlada por Megido.

A prosperidade da 'Nova Canaã' foi resultado da estabilidade do setor rural e do vibrante intercâmbio com a Fenícia. As cidades do norte provavelmente negociaram produtos secundários de nichos de horticultura nas terras altas, servindo como comunidades de acesso para essas commodities. A atividade de produção de cobre é evidente em muitos dos principais sítios dos vales de Jezrael e do Jordão. (FINKELSTEIN, 2015, p. 50)

Segundo Knauf e Guillaume, este reavivamento político e econômico da região foi impulsionado por uma espécie de

mundo multipolar com os centros filisteus ao sul, a Fenícia ao norte e a zona de produção e de distribuição de cobre no vale do Jordão e na Arabá. [...] O tráfego entre a costa e o Vale do Rift (depressão geológica em que estão o Rio Jordão e o Mar Morto e que se estende até o sul da África) através do Vale de Jezreel, da passagem de Siquém e do planalto de Benjamim sustentou a economia das tribos que controlavam estes locais" (2016, p. 44).

O mercado do cobre foi fundamental para o desenvolvimento da região montanhosa de Israel. As minas de cobre (Timna, Feinan, Khirbat em-Nahas) estavam na Arabá, ao sul do mar morto, mas, sua principal via de escoamento ao norte usava o vale do rio Jordão. E havia várias travessias do vale do Jordão em direção às planícies costeiras dos filisteus e dos fenícios, algumas passavam por Jerusalém e por Gabaá-Gabaon; outras por Tel Rehov, ao sul de Bet Shean, ou ainda por Siquém (KNAUF; GUILLAUME, 2016, p. 64). Estes novos ambientes sociopolíticos e a nova ordem econômica facilitaram a adoção de novas técnicas. E vice-versa, a adoção de novas técnicas está em função da realização da nova ordem territorial e social.

A Palestina e todo o oriente próximo viram entre os anos $1.200 \mathrm{e}$ 1.000 a.C. a instalação progressiva de uma série de inovações tecnológicas. É a época da difusão do ferro. Apesar das cidades ainda privilegiarem o uso do cobre para a fabricação de armas e instrumentos de bronze, paulatinamente o ferro vai se impondo na região (1Sm 13,19-23) (SCHWANTES, 1984, p. 66). O ferro tem a vantagem de poder ser elaborado a partir de equipamentos modestos, ao alcance de ferreiros das vilas ou de grupos itinerantes sem 
depender das cidades. É também a época da criação do alfabeto, muito mais democratizante do que o complicado sistema da escrita cuneiforme mantido pelas cidades estado cananeias. O alfabeto ainda terá um uso bastante limitado, mas expande-se pelas rotas comerciais do Mediterrâneo e nas trilhas das caravanas na península arábica. Relacionadas às caravanas está também a domesticação e a utilização de camelos na área iraniana, e dos dromedários na área próxima da Palestina. A utilização maciça destes animais se dará a partir da metade do século X quando irão penetrar os centros do oriente próximo (FINKELSTEIN; SILBERMAN, 2003, p. 58-59). Eles podiam transportar cargas maiores que os jumentos, e em ambientes em que os jumentos não conseguiam. Isso ampliou as comunicações comerciais para dentro das grandes áreas desérticas da Arábia, da Ásia central e depois também para o Saara. Esse fato diminui a importância de certas tribos e acentua a importância das tribos de criadores de camelos, que tiveram controle exclusivo sobre percursos desérticos e criaram cidades na trilha das caravanas que podiam rivalizar com as cidades estado. As táticas de guerra também se alteraram com o uso dos camelos como montaria. Os cavalos, anteriormente usados para puxar carros de guerra, passam a ser usados como montaria. Tribos com camelos ou cavalos podiam levar vantagens sobre os exércitos das cidades, compostos por carros de guerra apoiados por uma infantaria de camponeses convocados para esse serviço.

As inovações alcançam também o comércio marítimo. Assim como os camelos e dromedários ampliaram o comércio terrestre, barcos com novo arranjo de quilha, timão e velame incrementaram o comércio marítimo. A navegação costeira, de cabotagem, é complementada com novos barcos capazes de navegar em alto mar, que possibilitou uma explosão do tráfego comercial no Mediterrâneo, capitaneada pelos fenícios (LIVERANI, 2008, p. 72-75)

O crescimento do comércio também impulsionou transformações culturais e técnicas na agricultura, de onde vinha a maior parte dos produtos comerciais. Florestas foram desmatadas (Js 17,17-18) e encostas foram transformadas em terraços (Jz 5,18) em vários níveis para ampliar a terra agriculturável. Canais foram construídos para aproveitar as águas dos rios temporários (wádis) retidas por barragens. Cavavam-se poços mais profundos. Passou-se a utilizar um reboco à base de cal para impermeabilizar cisternas (LIVERANI, 2008, p. 75-78).

Esse conjunto de inovações não se desenvolveu de repente nem ao mesmo tempo. Algumas técnicas foram se firmando progressivamente 
(ferro, alfabeto), outras tornaram-se mais comuns (terraços, cisternas), e outras vieram no final do período (barragens e canais). Transformaram o território e a cultura e marcaram a transição do período do Bronze Recente para o período do Ferro I, o que aconteceu entre os anos 1180 e 1130 a.C.?. Por detrás desta transição está a chegada dos "povos do mar". Eles trouxeram várias destas novidades tecnológicas e impulsionaram outras. Os distúrbios sociais causados pelas diversas guerras travadas por eles nas planícies costeiras, somados à períodos de seca e distúrbios climáticos, juntamente com as novas tecnologias irão aumentar o número de assentamentos e a população nas montanhas. O número de assentamentos nas montanhas, que fora relativamente alto no período do Bronze Médio (2000 - 1550 a.C.), com aproximadamente 220 assentamentos, com um total de 40 mil camponeses, ao redor de centros fortificados como Hebron, Jerusalém, Betel, Silo e Siquém (FINKELSTEIN, 2003, p. 162), e decrescera para cerca de 25 assentamentos no período do Bronze Posterior (1550 - 1150 a.C.) voltou a crescer na época do Ferro I, quando formaram-se

inúmeras pequenas comunidades rurais e uma população de cerca de 45 mil camponeses em 250 sítios. Gradualmente o sistema evoluiu para um sistema maduro de grandes cidades, centros comerciais de tamanho médio e pequenas aldeias (FINKELSTEIN, 2003, p. 163).

Os primeiros assentamentos se deram no planalto central. Estas áreas, juntamente com a Galileia, com pluviosidade maior, também receberam os assentamentos mais densos. Ali os contingentes demográficos vindos da agricultura nas planícies irão fundir-se com "elementos tribais já existentes", firmando uma população bastante heterogênea (LIVERANI, 2008, p. 81). Percebe-se "maior continuidade com a cultura "cananeia" na baixa Galileia e em Manassés, e uma ocupação radicalmente nova nas regiões de Efraim e Benjamim, e depois também na alta Galileia e no Negev. Crescimento semelhante também é comprovado na Transjordânia setentrional, entre os rios Yabboq e Yarmuk, região de Gilead/Galaad. Ali o número dos sítios

\footnotetext{
A datação diverge entre os autores. Liverani demarca o período do Bronze Recente entre os anos 1550-1180 a.C., e o período do Ferro I de 1180-900 a.C. (2008, p. 32). Finkelstein considera esta datação "conservadora" e define o final do período do Bronze no ano 1130 a.C., quando se inicia o período do Ferro I, que segundo ele vai até 950 a.C. (2005, p. 22). No desenvolvimento deste artigo adotaremos a datação conforme a "baixa cronologia" proposta por Finkelstein e Piasetzky (2011, p. 50-54), apresentada resumidamente por Israel Finkelstein na obra The forgotten kingdom (2013, p. 6-10)
} 
de assentamento no final do período do Bronze passou de 32 para 218 no início do Ferro I, num crescimento parelho com o planalto central onde, no mesmo período o número dos sítios passou de 29 para 254 (LIVERANI, 2008, p. 81-82). Certamente neste período, o grupamento humano nomeado Israel na Estela de Merneptah no final do século XIII, se consolidará com a conformação das tribos de Efraim, Benjamim e grupos da região de Jabes Gilead/Galaad, uma vez que possivelmente a tribo de Manassés ainda não existisse (KNAUF; GUILLAUME, 2016, p. 68).

\section{Os filisteus buscam controlar as montanhas}

O incremento da produção camponesa, propiciado pelo crescimento da população, pela introdução do ferro e do boi na agricultura (Ex 21,2822,14 pode conter memórias deste período), a ampliação e intensificação do comércio, farão aumentar o olhar da cobiça para as regiões montanhosas da Palestina central. A produção excedente e o movimento comercial nas montanhas levam os filisteus a desejar integrar as regiões montanhosas e o planalto central com suas rotas comerciais às áreas costeiras por eles dominadas, e assim controlar o a produção e o comércio do nascente Israel. Esse movimento filisteu deve ter acontecido por volta de 1030 a.C.

Por "filisteus" atualmente devemos entender um conjunto emaranhado de grupos de variadas origens étnicas e culturais, "um fenômeno trans regional de vigorosos bandos de guerreiros com antecedentes da região do Mar Egeu e da Anatólia, ativo em todo o oeste do Mediterrâneo durante os últimos séculos do final do segundo milênio a.C. (KOCH, 2017, p. 192193)". Estes bandos começaram a chegar nas regiões planas de Canaã desde o século XIII, durante o reino de Ramsés II. Os filisteus não são frutos de um único movimento migratório, nem de uma mesma origem e nem possuem uma única trajetória rastreável. A emergência da cultura filisteia se deu após um longo e complexo processo que ocorreu em várias décadas, com vários eventos migratórios, "muitos vetores, múltiplas origens, diversas experiências socioeconômicas dos diversos povos que se amalgamaram aos filisteus (MAEIR; HITCHKOCK, 2017, p. 248)".

Os filisteus também não tiveram um único centro gravitacional. Ele foi mudando durante o curso da Idade do Ferro de uma localidade para outra: "No Ferro I Ekron era o centro, assentamento importante e talvez o maior da Filistia. Sua destruição no final do séc. X abriu o caminho para a 
a ascenção de Gat, que chegou em seu auge no meio do séc. IX. E quando Gat foi desruída....(FINKELSTEIN, 2007, p. 521)".

Os camponeses israelitas irão enfrentar e resistir ao avanço filisteu que provavelmente foi comandado a partir de Gat. Gat foi uma grande e próspera cidade desde o início do Ferro I (ao redor do ano 1200 a.C.) até o final do Ferro IIA, quando foi destruída por Hazael, aproximadamente no ano 830 a.C. Era uma extensa cidade, incluindo uma parte alta e uma parte baixa, com cerca de 40 a 50 hectares, o que fazia dela "uma das maiores cidades do Levante naquele tempo (MAEIR; HITCHKOCK, 2017, p. 253)”. E apesar de os textos bíblicos apontarem um domínio judaíta sobre os filisteus, "se alguém quisesse falar de reinos dominantes no sul do Levante, no Ferro IIA, o reino de Gat seria um candidato muito mais provável do que o nascente reino de Judá (MAEIR; HITCHKOCK, 2017, p. 253)"”. É Gat que emerge como o centro político dominante neste período. $\mathrm{E}$ mesmo com relações bidirecionais com a Filistia no oeste, e com a Shefelá e as regiões das montanhas centrais a leste, "é seguro admitir que o reino de Gat irradiava poder tanto para este como para leste (MAEIR; HITCHKOCK, 2017, p. 255)". E nisso as narrativas bíblicas combinam com a arqueologia, pois no período do antigo Israel, mencionam especialmente a Gat como a base dos filisteus.

A chamada "Narrativa da Arca" (1Sm 4-6 e 2Sm 6,1-19) guarda a memória de um combate ocorrido antes da instituição da monarquia, entre "israelitas" e filisteus, que termina com uma acachapante derrota do exército

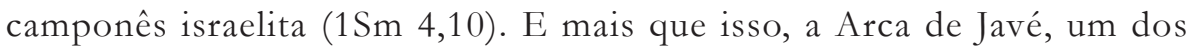
principais símbolos religiosos dos camponeses da área montanhosa central, é tomada pelos filisteus $(1 \mathrm{Sm} \mathrm{4,11).} \mathrm{Certamente} \mathrm{nesse} \mathrm{momento} \mathrm{os} \mathrm{filisteus}$ também adentraram no território dos israelitas, destruíram o santuário de Silo, tradicional santuário da arca e local de assembleia dos camponeses e mobilização do seu exército. A Bíblia não guarda a narrativa desta destruição comprovada pela arqueologia, mas a tradição profética no livro de Jeremias, um descendente dos sacerdotes que eram guardiões da arca ( Jr 1,1), recorda esse episódio em Jr 7,12-15 e em 26,9, Cf. S1 78,60 (FINKELSTEIN, 2015, p. 40-44.70-72).

A tomada da arca e a destruição do santuário de Silo pelos filisteus, e consequentemente também a vitória dos filisteus sobre o exército camponês

Contra Avram Faust, que em seus escritos sustenta que no séc. X a.C., particularmente no tempo do rei Davi, os filisteus eram política e culturalmente dominados pelo reino de Judá (FAUST, 2013; 2018) 
tribal, devem ser fatos históricos. A arqueologia encontra sinais de uma destruição de Silo que deve ter ocorrido "na segunda metade do século XI a.C.”, isto é, entre os anos 1050 e 1000 a.C. (FINKELSTEIN 2015, p. 42-43; DEVER, 2017, p. 159). Adota-se aqui a opinião de que isto se deu em uma data próxima do ano 1000 a.C. E apesar de a arqueologia não ter encontrado restos do santuário (FINKELSTEIN 2015, p. 41-42) ${ }^{9}$, cremos que a tradição israelita não inventaria, ou transmitiria narrativas inventadas, em que o Deus Javé, que virá a ser o grande Deus de Israel, aparece como incapaz de guardar seu povo e seu próprio santuário e é derrotado de forma humilhante. Esses dolorosos acontecimentos eram conhecidos e devem ter ocorrido ${ }^{10}$. Pois a tradição precisou dar-se ao trabalho de elaborar narrativas para mostrar que Javé não fora derrotado e nem perdera o controle da situação. E assim, criaram uma narrativa com a Arca de Javé humilhando os filisteus e Dagon, o Deus nacional dos filisteus. Nesta narrativa, embora tendo sido capturado, Javé vence Dagon não somente no território filisteu, mas dentro do santuário do próprio Dagon (1Sm 5,1-6,15).

O exército camponês que foi derrotado pelos filisteus era mobilizado pelos anciãos das aldeias das regiões ao redor de Silo (1Sm 4,3). Era um exército voluntário convocado pelo toque da trombeta. Dependia da solidariedade e da saúde econômica das vilas camponesas.

O fracasso das forças armadas de Benjamim, provavelmente culminou com a instalação da $n^{e} t s i v$, que pode ser uma estela, um governador, uma guarnição ou posto de controle dos filisteus em Gaba, ou Gabaá, na tribo de Benjamim (1Sm 13,3) (KAEFER, 2016, 416-417). O colapso do "exército popular" e a destruição de Silo devem ter acontecido algum tempo antes da reorganização guerreira capitaneada por Saul. O avanço dos filisteus foi determinante para a ascensão de Saul.

Com a crescente demanda de produtos para o comércio criam-se as condições para a transformação de algumas aldeias camponesas em núcleos urbanos: "por volta do ano 1000 a.C. a cultura das vilas das montanhas vai rapidamente se transformando em uma sociedade proto-urbana, cada vez mais centralizada" (DEVER, 2001, p. 267). E será o surgimento de uma elite que

\footnotetext{
9 Finkelstein diz que o local foi abandonado após a destruição (2015, p. 71). Liverani afirma que a cidade, embora modestamente, estava ocupada nos tempos de Saul (2008, p. 124).

10 A destruição de Silo é brandida como exemplo por Jeremias, dizendo que o mesmo poderia acontecer a Jerusalém (Jr 7,12-15), o que fez com a elite de Jerusalém pedisse a pena de morte para ele (Jr 26,6.9).
} 
concentra e centraliza o poder econômico, político e militar que desembocará na instituição da monarquia (1Sm 9,1; 11,5-7; 25,2)

\section{Os "senhores", donos de bois, rebatem os filisteus}

A maioria dos assentamentos na região montanhosa por volta do ano 1000 a.C. são pequenos, com mais ou menos 1 hectare, relativamente isolados uns dos outros e sem muralhas fortificadas, ou grandes obras de arquitetura. Não há muitas evidências de acúmulo de riqueza ou poder neles e nem uma evidente hierarquização entre um assentamento e outro. Exceto em uma pequena região no planalto entre Gabaon e Betel que será o centro da nova unidade política, da qual se falará mais abaixo. Certamente nas montanhas centrais da Palestina, nas áreas de Benjamim, Efraim e Jabes de Galaad/Gilead, por volta dos anos 980 a.C. formou-se uma unidade política chefiada pelo Benjaminita Saul (1Sm 9,1-2). Elas serão a base da primeira entidade política territorial do norte israelita: a unidade política GabaonGabaá, chefiada pela casa de Saul. Essa unidade política ainda não reunirá todas as características de uma monarquia, mas será a primeira experiência consistente e duradoura de uma chefia politicamente centralizada em Israel.

Entretanto, não é fácil determinar qual a área de abrangência desta unidade política nascente. Inicialmente deve-se notar que Judá parece ainda não existir como tribo organizada. E a região da montanha de Judá deveria ser parte d de Benjamim. É difícil aceitar que Benjamim, tendo somente o pequeno território que lhe é designado depois da formação de Judá, pudesse ter força para governar outras áreas bem maiores, com mais terras férteis, e com mais pessoas, portanto com exércitos mais fortes. Por isso nos parece mais razoável compreender esta região como parte dos domínios de Benjamim. Há um significativo conjunto de textos bíblicos indicando que a região da montanha de Judá estava associada a Benjamim. Juízes 1,21, e Josué 18,28 relatam que Jerusalém pertencia a Benjamim. E há muitos indícios de que o território controlado pelos benjaminitas ia até uns 40 ou $50 \mathrm{~km}$ ao sul de Jerusalém. Portanto, Hebron que fica no ponto mais alto da montanha de Judá e Carmel na descida sul, na direção do Negev, estariam dentro das terras de Benjamim.

De fato, nessa época, “a região montanhosa de Judá, ao sul de Jerusalém foi habitada de maneira escassa por apenas um pequeno número de assentamentos"(FINKELSTEIN, 2015, p. 64). Estima-se que a população da região montanhosa central de Benjamim, Efraim e Manassés, viviam em 
torno de 38 mil pessoas, enquanto nas montanhas de Judá viviam somente pouco mais de 2 mil pessoas (GRABBE, 2007, p. 92).

$\mathrm{Na}$ chamada "História da ascensão de Davi ao trono" (1Sm 16 a 2Sm 6), Davi, ao fugir de Saul, passa por uma série de localidades todas ao sul de Hebron, e todas aparentemente sob o controle do benjaminita Saul: Odolam (1Sm 22,10; Ceila (1Sm 23,12); Deserto de Zif (1Sm 23,14); Horesa (1Sm 23,19); Maon $(1 \mathrm{Sm} 23,24)$ e também vai assediar o calebita Nabal, em Carmel (1Sm 25), local que possivelmente marcava o limite sul da jurisdição de Saul $(1 \mathrm{Sm} \mathrm{15,12).} \mathrm{Esse} \mathrm{mesmo} \mathrm{texto} \mathrm{também} \mathrm{se} \mathrm{refere} \mathrm{à} \mathrm{"terra} \mathrm{de} \mathrm{Judá”} \mathrm{(1Sm} \mathrm{22,5),}$ ou aos "clãs de Judá" (1Sm 23,23) e aos "anciãos de Judá" (1Sm 30,26) como uma referência às terras e aos clãs que habitavam a cadeia de montanhas ao sul de Jerusalém. Judá era o nome da principal montanha da região, e pouco se sabe de Judá antes da monarquia (GOTTWALD, 1986, p. 167).

\section{Saul, chefe de um "exército" permanente}

Com Saul Israel fará a sua primeira experiência significativa de uma centralização de poder. Possivelmente antes dele houve outras, como a de Abimelec, em Siquém (Jz 9). Pode ser que Abimelec, pouco antes ou depois do ano 1000 a.C., estivesse buscando reeditar um pequeno reino cananeu, que existiu no tempo das Cartas de Amarna (1370-1350 a.C.), o reino de Labayu. Com base em Siquém, Labayu e seus filhos, lutaram para manter e expandir, diplomaticamente e militarmente, um território que incluía as áreas montanhosas centrais e parte da área costeira até próximo de Jerusalém e parte das planícies da Transjordânia. O território relacionado com Labayu e seus filhos coincide com o que mais tarde será o reino do norte (FINKELSTEIN, 2015, p. 33-38).

Como se viu acima, na referência à destruição de Silo, os camponeses das montanhas centrais da Palestina possuíam uma espécie de "exército camponês". Mas este, porém, era sempre temporário. Os guerreiros eram desmobilizados quando as ameaças já não mais existiam. Voltavam a ser camponeses (cf. Jz 3,27; 4,6; 6,34-35) (DREHER, 2002, p. 9-16).

O exército do grupo de Saul, porém, já desde o início, é diferente. A narrativa bíblica conta que Saul era Benjaminita e membro de uma família abastada que possuía bois (1Sm 9,1). E para formar seu exército, ele espedaça uma junta de bois e envia os pedaços aos outros donos de bois que estavam entre as tribos, com a seguinte mensagem: "se alguém deixar de seguir Saul, é isto que vai acontecer a seus bois" (1Sm 11,5-7). Sua mensagem é dirigida, 
portanto, a um grupo muito específico: os donos de bois. E serão eles que enviarão os guerreiros e manterão o exército de Saul.

Várias narrativas bíblicas relatam como Saul tornou-se o chefe de Israel: sendo ungido por Samuel (1Sm 9,1-10,16); sendo escolhido por sorteio (1Sm 10,17-27); e sendo aclamado após uma vitória militar (1Sm 11,1-15) ${ }^{11}$. É possível que a narrativa da aclamação militar esteja mais próxima dos acontecimentos históricos. Provavelmente Saul começa sua carreira como líder militar de um grupo de guerreiros israelitas, mantidos pelos homens proprietários e donos de bois, organizados para defender a cidade de Jabes de Galaad, contra o avanço dos amonitas. A região de Jabes de Galaad era famosa por suas pastagens (Nm32) e pelo gado (Am 4,1). Certamente ali eram criados e dali provinham os bois utilizados nas tribos das montanhas de Israel.

A aliança de Israel com Jabes de Galaad situada no outro lado do Jordão, longe das áreas controladas pelos filisteus, criou o espaço estratégico para a organização do exército de Saul (ver KAEFER, 2016, p. 413-414). Esse acontecimento deve ser o substrato histórico que está por trás da narrativa de $1 \mathrm{Sm}$ 11,1-11. Depois da batalha, no entanto, o exército de Saul não será desmobilizado, e os guerreiros não retornarão às suas funções na agricultura. Pelo contrário, o exército será mantido e se tornará permanente. Essa decisão pode ter sido tomada em Gilgal $(1 \mathrm{Sm} 11,15)$, lugar que a tradição profética guardou como início da monarquia (Os 9,15).

\section{O centro de operações de Saul}

Juntamente com Jônatas, seu filho, Saul e seu exército certamente conseguiram expulsar os filisteus da região montanhosa de Israel, conforme o sumário muito favorável a Saul em 1Sm 14,47-52 (KAEFER, 2016, p. 420422). Ele estabeleceu seu centro de operações nos povoados do platô Gabaon - Betel (1Sm 13,16). Essa região compreendia "um grupo de sítios localizados no platô entre Gabaon e Betel, ao norte de Jerusalém." (FINKELSTEIN, 2015, p. 58). Nesse espaço de aproximadamente 20 por $15 \mathrm{~km}$ existiu no tempo de Saul um aglomerado de uns trinta pequenos sítios de povoação. Entre eles estão Gabaon, Betel, Masfa (Tell el-Nasbeh), Ai (et-Tell), Khirbet

11 Deve-se notar que estas narrativas são de épocas diferentes e com perspectivas diferentes sobre a monarquia: $1 \mathrm{Sm}$ 9,1-10,17 e 1Sm 11,1-15 são pró-monárquicas; enquanto $1 \mathrm{Sm}$ 10,17-27, é antimonárquica. Essa perspectiva antimonárquica aparece no relato que apresenta a monarquia como algo desejado pelo "povo" (1Sm 8,1-22) e no discurso de despedida do profeta Samuel (1Sm 12,1-24). Nas narrativas antimonárquicas, provavelmente pós-exílicas, instituir um rei significa rejeitar Javé (Cf. 1Sm 8,7; 10,19; 12,12) 
Radana (próximo de Ramalah), Tell el-Ful (entre Gabaon e Jerusalém) e Khirbet ed-Dawwara (mais próximo do vale do Jordão).

Estes povoados apresentam duas características principais. A primeira é que possuem fortificações com casamatas (em várias partes a muralha é dupla, com pequenas divisões fortificadas entre as duas paredes, o que torna a muralham mais resistente). Diferenciam-se do restante dos povoados israelitas, que em sua maioria não possuíam muralhas.

A organização necessária para a construção de um sistema com várias fortalezas desse tipo em um território muito pequeno aponta para algum tipo de poder concentrado, como o dos filisteus (por volta do ano 1000 a.C.) ou de um poder público centralizado, como o que deve ter existido com os donos de bois e Saul (por volta dos anos 980 a 958 a.C.). A fortaleza desenterrada em Gabaá de Benjamim "pode ter sido parte do quartel general de Saul" (MAZAR, 2003, p. 358). A outra característica desse grupo de povoados é que vários deles foram abandonados ou diminuídos no período do Ferro II, entre os anos 960-850 a.C. O abandono e a acentuada diminuição de alguns deles, entre os quais está Gabaon (FINKELSTEIN, 2015, p. 60-61), pode ser um indicativo do final da derrota da casa de Saul que aconteceu em torno de 958 a.C.

Saul não pode ser considerado exatamente um "rei". Era pouco mais que um líder tribal. Os textos na verdade o apresentam como um líder ou chefe tribal (nagid, 1Sm 9,16; 10,1). (KNAUF; GUILLAUME, 2016, p. 67.) "A estrutura burocrática de Saul é precária e ligada ao seu clã (1Sm 14,50-51)." Ele governava sob uma árvore, em sua cidade natal $(1 \mathrm{Sm} 22,6)$. Só tem um funcionário, que é Abner, chefe do exército e primo de Saul" (KAEFER, 2015, p. 40). Embora Gabaá de Saul (1Sm 10,26; 22,6; 23,19; 26,1), uma cidadela com muros duplos, com estruturas de casamata e elevações nos quatro cantos, lhe servisse como capital e fosse a sua base de atuação, Saul parece não ter tido uma religião oficial e nem um sistema de coleta de tributos, que caracterizam as monarquias consolidadas mais tarde em Israel. Seu exército devia ser mantido pelos donos de bois.

E o "exército" de Saul era armado basicamente com "paus e pedras" (1Sm 13,22; 17,43), e não se distinguia muito dos bandos de hapirus/ hebreus $(1 \mathrm{Sm} 13,3 ; 14,11)$. Os hapirus eram grupos pobres, marginalizados, maltrapilhos, que não estavam integrados nem nos espaços urbanos e nem nos espaços rurais que compunham o sistema das cidades daquela época, e se organizavam em bandos para pequenos assaltos ou para servirem como mercenários a quem melhor lhes pagasse (cf. 1Sm 14,21). 
As dimensões da jurisdição de Saul, de acordo com o que se pode retirar das narrativas bíblicas, incluíam:

- Jabes de Galaad, a poucos quilômetros no outro lado do Jordão (1Sm $11,1-15 ; 31,8-13)$,

- Regiões dos arredores de Siquém, pois Saul morre lutando contra os filisteus no monte Gelboé (1Sm 31,1), embora possa simplesmente ter sido empurrado para lá durante o combate.

- Hebron. Se o substrato de $1 \mathrm{Sm} 17$ corresponde a história, parece certo que Hebron estava sob domínio de Saul. Naquela narrativa se informa que Jessé, o pai de Davi, um efrateu que vivia próximo de Hebron, em Belém, enviou alguns de seus filhos para lutar no exército de Saul (1Sm 17,12-14). Isso indica que o território de Judá estava dentro da jurisdição militar de Saul (HALPERN, 2017, p. 342.). Talvez fizesse parte do território de Benjamim.

- E tinha seu limite sul na localidade de Carmel, uns $15 \mathrm{~km}$ ao sul de Hebron, onde viviam Nabal e Abigail (1Sm 25). E Nabal, ao negar ajuda a Davi e seu bando de fugitivos, parece estar "contando com a proteção de Saul" (OROFINO, 1999, p. 270). Em 1Sm temos a notícia de que Saul fora colocar "uma mão" (uma matsevah?) em Carmel (1Sm 15,12), possivelmente reivindicando poder político e militar sobre aquela área, ou um marco dos limites de sua jurisdição (cf. MILLER; HAYES, 2006, p. 141).

Essa área mais ou menos coincide com o que se diz do reino de Isboset, o filho de Saul entronizado por Abner em Maanaim, depois da morte de Saul. Isboset seria rei "sobre Galaad, sobre os Aseritas, sobre Jezrael, Efraim, Benjamim e sobre todo Israel” (2Sm 2,9). O "todo Israel” deve ser excluído do domínio histórico de Isboset, porque é uma expansão acrescentada pela redação deuteronomista do século VI a.C., que quer dar a entender que Saul comandava as doze tribos e todo o território de Israel. De todo modo, o poder de Saul cobre uma região bem mais modesta do que a que lhe atribui a narrativa deuteronomista. Historicamente o território controlado por Saul, portanto, compreendia somente uma pequena parte da Transjordânia e da região montanhosa da Palestina central ${ }^{12}$. Muito provavelmente estavam com Saul as áreas de Benjamim, Efraim e o núcleo galaadita da futura tribo de Manassés.

12 Algo semelhante é apontado por KAEFER, 2014, p. 161-162. O território ligado a Saul na Transjordânia deveria ser bem pequeno. Talvez circunscrito aos territórios mencionados no que se pode chamar de "Ciclo de Galaad" (Gn31,1-33,17), um conjunto de narrativas que reivindica para Israel o controle de quatro vilarejos na Transjordânia- dizendo que foi Jacó quem lhes deu seus nomes - Galaad $(31,47)$; Maanaim $(32,3)$; Penuel $(32,31)$ e Sucot $(33,17)$. Poderia ser o "Galaad" citado em Jz 5,17. 


\section{Quem matou Saul?}

O governo de Saul deve ter durado uns 22 anos, de 980 a 958 a.C. (LIPINSKI, 2018, p. 50) ${ }^{13}$, ou pouco mais. Pode-se chegar a este número considerando o que se pode tirar de histórico dos relatos a seu respeito e das escavações arqueológicas na região. O versículo de $1 \mathrm{Sm} \mathrm{13,1} \mathrm{que} \mathrm{trazia}$ esta informação está corrompido. Os manuscritos e as intepretações trazem números que variam entre 2, 22, 32 e 42. Seu comando termina com a morte dele e de seus filhos guerreiros. De acordo com 1Sm 31, o exército de Saul foi destroçado pelos filisteus, e os corpos de Saul e de seus filhos foram pendurados e expostos nas muralhas da cidade de Bet Shean (1Sm 31,9). E a informação de que Saul e seus filhos maiores pereceram na guerra com os filisteus provavelmente é histórica. E isso deve ter acontecido por volta do ano 958 a.C. Situar a data de sua morte em uma data tão posterior como a da invasão do faraó egípcio Shoshenq/Sisac obriga a ver quase como simultâneos os reinados de Saul, Davi, Salomão, Roboão e Jeroboão. A cronologia ficaria totalmente conturbada.

Porém, é possível que egípcios tenham participado da batalha em que Saul morreu. Bet Shean existia desde os anos 3400 a.C. A partir dos anos 1450 a.C. foi integrada aos domínios egípcios. Sua localização era militarmente e comercialmente estratégica, controlava o entroncamento das estradas que ligam a planície costeira e o planalto central com as terras do outro lado do Jordão e, ao norte, com a Síria. Por isso havia ali uma das maiores guarnições egípcias na Palestina. Por volta dos anos 1200 a.C. Bet Shean foi atacada e vencida no contexto da invasão dos "povos do mar", dentre os quais estavam os filisteus. No entanto, logo a pós sua destruição a cidade foi reconstruída, porém revelando muitos sinais de continuidade com a ocupação anterior (LIVERANI, 2003, p. 105. MAZAR, 2010, p. 259-261).

Historicamente o estabelecimento dos filisteus e de outros grupos dos "povos do mar" na planície costeira da Palestina, nos vales de Jezreel e arredores, diminuiu a presença de exércitos egípcios na região. Porém, isso não significa que o Egito estava fora da cena. O Egito sempre viu como essencial o controle da costa, especialmente da "Via de Hórus", que protegia a entrada ao delta do Nilo pela faixa costeira de Gaza. O domínio de toda a costa marítima era importante para o acesso aos cedros do Líbano. Os cedros, na região, eram as únicas árvores que podiam fornecer travessões

13 KAEFER (2016, p. 416), também pensa que o reinado de Saul deve ter durado 20 anos, embora situe o reinado de Saul em outra época. 
para as grandes construções. Os troncos, amarrados em forma de balsa, eram transportados pela costa, através das cidades fenícias (1Rs 5,16-23), até adentrar no delta do rio Nilo. E era essencial para o Egito também manter o controle sobre a fértil planície de Jezrael e o entroncamento das rotas militares e comerciais que ali havia. Possivelmente o Egito seguiu considerando o território cananaico-filisteu da costa e da planície de Jezrael como seu. Isso fica claro pelo fato de cidades que a arqueologia comprova que foram importantes centros administrativos e militares dos egípcios, como Megido, Jezreel e Bet Shean, terem sido reconstruídas logo após sua destruição e em "evidente continuidade" (LIVERANI, 2008, p. 105.) com a ocupação e as funções que exerciam antes da destruição.

É preciso levar em consideração também que a própria instalação dos filisteus na planície costeira acima de Gaza, e de outros grupos dos "povos do mar" em Dor, contou "com o aval faraônico, na tentativa de manter por interposta pessoa um controle que não se conseguia mais exercer somente por meio da presença de 'residências' e chefes de guarnições egípcios." (LIVERANI, 2008, p. 105). É provável que já “o próprio Ramsés III, ou o mais tardar um de seus primeiros sucessores, tenha assentado os filisteus na planície litorânea...como colonos militares egípcios, na esperança de que constituíssem um baluarte contra outros povos do mar que pressionavam a partir do norte." (DONNER, 2000, p. 48). Liverani aponta na mesma direção: "A contenção dos povos do mar aconteceu com a condição de os deixar se alojar em massa na costa palestina, desde que se mantivesse algum controle sobre as possessões asiáticas." (2008, p. 67) Isto é, os filisteus eram aliados dos egípcios, e talvez atuassem mais como vassalos e intermediários da dominação egípcia na região do que como um poder autônomo.

Muito possivelmente na batalha contra o exército de Saul, os filisteus tiveram o apoio das forças egípcias estacionadas em Meguido, Jezreel e na própria Betsã. Como a batalha final aconteceu no monte Gelboé, nas franjas da planície de Jezreel, pode ser que os filisteus e egípcios entraram em ação para impedir que o grupo de Saul, que congregava forças de Benjamim, Efraim e Galaad/Manassés, avançasse sobre a planície de Jezreel. Ou pode ser também que Saul simplesmente tenha sido acuado para aquelas bandas pela pressão de seus adversários. O que parece certo é que por volta dos anos 958 a.C., Saul e seus filhos são mortos e seu exército sofre pesada derrota no monte Gelboé (1Sm 31). O fato de os corpos de Saul e de seus filhos terem sido expostos nas muralhas de Bet Shean, é um forte indicativo de 
que os interesses dos filisteus correspondiam aos interesses dos egípcios, e que eles eram aliados. Deve-se notar também que, possivelmente Davi e seu grupo participaram desta batalha como mercenários ao lado das forças que mataram Saul (1Sm 28,1-2; 29,2-3; 2Sm 16,5-8) (HALPERN, 2001, p. 78-80; BADEN, 2016, p. 111-118).

Muito mais não sabemos sobre Saul. Os textos bíblicos sobre ele são contraditórios. Há uma camada de textos bastante favoráveis e elogiosos a Saul (1Sm 9,1-10,17; 11,1-14; 13,1-7.18-23; 14,1-23.47-52), que possivelmente vêm de tradições do reino do norte. Essa no, entanto, está quase soterrada por uma outra camada, posterior, destinada a diminuir e desgastar Saul para justificar e elevar a Davi (1Sm 10,8-18.17-27; 13,7b-15; 14,23b-46; 15,1-35; e todo o bloco da chamada "História da Ascensão de Davi ao trono", que está em $1 \mathrm{Sm} 16$ - 2Sm 6). A história de Saul está imbricada com a história de Davi. Se pode não ser tão clara a participação de egípcios no massacre de Saul e seus filhos, a participação de Davi parece ser bem mais evidente. E Davi certamente foi vassalo dos filisteus em todo o seu governo.

\section{Davi cresce dentro da casa de Saul}

Não sabemos muito também sobre Davi, mas sua existência histórica é confirmada pela arqueologia. Ele é mencionado na chamada "estela de Dã". Esta estela teria sido erigida pelo rei Hazael, de Damasco/Aram por volta de 841 a.C., celebrando sua vitória sobre uma coalizão formada pelo rei Jorão, que governou Israel mais ou menos entre 851 a 841 a.C., e pelo rei Ocozias, que foi rei de Judá em 841 a.C. A estela indiretamente menciona Davi referindo-se a Ocozias como rei da Byt-David, "casa de Davi" (KAEFER, 2012, p. 33-46). Para a maioria dos estudiosos isto é uma prova extra bíblica da existência de Davi e do seu reino. Nem Saul e nem Salomão são mencionados fora da Bíblia.

A Bíblia nos apresenta três narrativas sobre como Davi entra na história da monarquia. A primeira é a narrativa da "unção de Davi” (1Sm 16,1-13). Porém esta unção não será citada e nem é pressuposta em $1 \mathrm{Sm} \mathrm{17,} \mathrm{quando}$ Davi entra atua entre seus irmãos, no exército de Saul e nem qualquer outra parte da história de Davi. Nem mesmo em 2Sm 2,4, quando os "homens de Judá" ungiram a Davi como rei da "casa de Judá", e nem em 2Sm 5, quando se diz que os "todos os anciãos de Israel" ungiram a Davi como "rei de todo Israel”. Portanto é bem provável que a narrativa da unção de Davi em 1Sm 16 seja uma criação literária posterior, e não represente um fato histórico. 
A segunda é a narrativa que nos apresenta Davi sendo chamado à corte de Saul como uma espécie de "musicoterapeuta", para acalmar ao rei Saul quando ele entrava em crise, tomado por um "mau espírito enviado por Javé" (1Sm 16,14-23). Nesta narrativa, entre outros atributos, Davi é apresentado como sendo um "valente guerreiro" $(16,18)$. Saul gosta muito de Davi e requisita-o para que fique junto dele como "seu escudeiro" $(16,21)$. Esta narrativa é de uma fonte independente. E cria conflitos com a narrativa seguinte, $1 \mathrm{Sm}$ 17. Em 1Sm 17 Davi é um menino inexperiente em guerras (17,33.38-39); sua presença no campo de batalha, que seria normal sendo o escudeiro de Saul, é questionada por seu irmão mais velho $(17,28)$; e ali nem Saul e nem Abner, seu principal general, conhecem Davi (17,55-58). A apresentação de Davi como "musicoterapeuta" faz parte de uma narrativa maior, elaborada para diminuir o brilho de Saul e apresentar e justificar a derrota de sua família e a vitória de Davi, como um movimento patrocinado por Javé. Desgostoso com Saul, Javé afasta seu Espírito de Saul, enviando para ele somente um "mau espírito" $(16,14)$ e fazendo pousar seu Espírito sobre Davi (16,18; cf. 16,13). Essa narrativa teria sido criada posteriormente.

A terceira é a que conhecemos como a "luta de Davi contra Golias" (1Sm 17,1-18,5). É possível que as informações históricas sobre como Davi tenha entrado no círculo mais próximo dos homens de Saul estejam no substrato primitivo desta narrativa luta contra um contigente de guerreiros filisteus de Gat (1Sm 17,4.23.52). Hoje ela nos apresenta um pequeno menino enfrentando e vencendo a um gigante guerreiro muito bem armado. Porém por baixo dessa imagem mitificada pode-se perceber que Davi era um guerreiro anônimo do exército de Saul e tinha uma "tenda" no campo de batalha (1Sm 17,54). Inicialmente Saul não o conhece. Mas depois de uma corajosa e eficiente atuação - provavelmente Davi enfrentou, armado com uma funda, um guerreiro armado com armas de ferro, talvez o chefe de um destacamento filisteu ${ }^{14}$, e sua vitória ajudou aos israelitas vencerem um confronto com alguns filisteus - Saul chama Davi a sua presença e lhe pergunta quem é seu pai (1Sm 17,55-58), e requisita-o para fazer parte do grupo de militares que estavam mais próximos dele (1Sm 18,3; cf. 14,52).

14 Uma exegese desta narrativa é dada em DIETRICH, L. J. O processo e a função social da produção da imagem de Davi como pastor que fala em nome de Yhwh zebaot, em 1 Samuel 17.1-18,5. 2002. 286 p. Universidade Metodista de São Paulo. São Bernardo do Campo. São Paulo. 
Possivelmente algo assim tenha ocorrido historicamente. Davi entra na história como um guerreiro sob o comando de Saul. E esta deve ter sido uma de suas virtudes: ser um bom guerreiro. Devia ser também um bom estrategista. Alguém que "não dá pontos sem nó". Vitorioso nas tarefas que lhe eram designadas, Davi torna-se chefe dos "homens de guerra" (18,5; 18,13). E como oficial do exército de Saul, Davi casa-se com Micol, uma das filhas de Saul, entrando na corte e na família de Saul e tornando-se apto a pleitear a sucessão. O rápido crescimento de Davi dentro do exército de Saul, e ações como seu casamento com uma das mulheres do clã de Saul, parecem indicar que Davi buscava entrar na linha sucessória. Os textos da chamada "História da Ascensão de Davi ao trono" (1Sm 16 - 2Sm 6), produzidos pela casa de Davi, procuram mostrar enfaticamente que Davi não conspirou para chegar ao poder. A transferência do poder de Saul para Davi teria sido decisão e obra de Javé (1Sm 13,13-14; 15,11.23.28; 16,1.12-13).

Mas historicamente parece que Davi tramou para chegar ao poder, e tendo despertado as suspeitas da família de Saul, é obrigado a fugir. No deserto Davi forma um bando com "todos os oprimidos, todos os endividados e todos os descontentes" por terem perdido sua autonomia ou suas terras $(1 \mathrm{Sm} \mathrm{22,2)} \mathrm{com} \mathrm{o} \mathrm{crescimento} \mathrm{do} \mathrm{poder} \mathrm{e} \mathrm{a} \mathrm{interferência} \mathrm{dos}$ donos de bois no tradicional sistema de distribuição das terras (1Sm 22,7). Junta ao redor de si cerca de seiscentos homens (1Sm 23,13; 25,13; 27,2; $30,9)$. Com isso acirra-se o confronto. De um lado um exército mantido pela elite da sociedade e de outro um bando de marginalizados se organizando militarmente, mas que precisa manter-se com saques e tributos (1Sm 25,7-8). "É possível que tenha sido nesse meio, no deserto e ao lado dos excluídos, dos sem-terra, que nasceu a história popular de um líder chamado Davi [...], um líder popular que comandava um bando de excluídos, a estilo dos antigos hebreus-hapirus e que atuava no sul de Judá, entre Hebron, Bersheva e Siceleg"(KAEFER, 2015, p. 44).

E em sua fuga Davi irá juntar-se aos filisteus. Será um mercenário dos filisteus de Gat (1Sm 21,11.13; 272.3.4.11). Esta deve ser considerada uma informação histórica. Os filisteus foram uns dos maiores inimigos de Israel. E o fato de Davi ter atuado ao lado dos filisteus pesa como uma grave mancha em seu currículo. É difícil pensar que a família de Davi, que tomou o comando de Benjamim e de Judá depois que Saul e sua família foram mortos pelos filisteus e é quem faz a redação final do texto, teria inventado tal coisa. Mas também não podiam simplesmente apagar isso da história de Davi. O 
fato era conhecido pelos membros da tribo de Benjamim e por todos os que viveram aquele período. O que fazem então é criar uma narrativa muito bem elaborada na qual se esforçam para inocentar Davi.

O fato é que os textos informam que até o dia em que os filisteus decidiram subir contra o exército de Israel e mataram Saul, Jônatas e outros filhos de Saul, Davi era mercenário dos filisteus (1Sm 28,1-2; 29,2-3). E não foram somente estas mortes que marcam o caminho de Davi até o trono. As acusações de conspiração e assassinato que pesavam contra Davi nos são transmitidas através das palavras de um Benjaminita, da família de Saul, chamado Semei, que grita contra Davi: "Vá embora, fora daqui homem sanguinário, homem perverso! Javé fez recair sobre você todo o sangue da casa de Saul, cujo reino você usurpou! [...] Eis que agora você está na desgraça, pois você é um homem sanguinário!" (2Sm 16,5-8). "Essa passagem parece desvelar o que as narrativas bíblicas tentam encobrir." (KAEFER, 2015, p. 43)

$\mathrm{Na}$ "História da Ascensão de Davi ao Trono" (1Sm 16 - 2Sm 6), escrita exatamente para inocentar Davi diante das acusações levantadas contra ele, menciona-se a morte de outro filho de Saul e a morte de Abner, o principal comandante do exército de Saul.

As acusações contra Davi são graves: conspiração (1Sm 20,30-31; 22,13), usurpação do poder e assassinatos. A História da Ascensão de Davi diz que ele não buscou o poder, não tramou para toma-lo e nem matou para alcança-lo. Apresenta-o como fiel servo de Saul, que teve de buscar refúgio entre os filisteus para fugir para proteger a si mesmo e a sua família da inveja e da fúria insana de Saul. Essa narrativa também quer fazer acreditar que Davi teve a oportunidade de matar Saul por duas vezes, mas não ousou "levantar a mão contra o ungido de Javé". A narrativa também conta que Davi enganava os filisteus, fingindo servir aos interesses dos filisteus atacava os inimigos de Judá (que Davi foi dispensado do exército filisteu e não estava entre eles quando os filisteus mataram Saul e seus filhos na batalha do monte Gelboé (1Sm31). Afirmam que Javé estava com Davi e conduzia a história dessa forma. No entanto, historicamente, Davi só consegue se fixar em Judá após a morte de Saul, do comandante de seu exército e de todos os seus filhos capacitados para a sucessão ${ }^{15}$.

15 Para uma análise crítica sobre Davi, ver o livro: BADEN, J. Davi: a vida real de um herói bíblico. Rio de Janeiro: Zahar, 2016. Este autor baseia-se especialmente em HALPERN, B. David's Secrets Demons. Messiah, murderer, traitor, king. Grand Rapids, Michigan: Wm. B. Eerdmans Publishing, 2001. 


\section{Davi em Hebron, a família de Saul em Maanaim: dois pequenos reinos em guerra}

A tribo e o reino de Judá só se formam após Saul e seus filhos mais velhos terem sido massacrados na guerra com os filisteus (1Sm 31). Como foi visto, anteriormente, a região da montanha de Judá estava dentro da jurisdição do Benjaminita Saul. E muito provavelmente, a constituição da tribo de Judá tenha acontecido somente no momento da constituição do reino de Judá. A Tribo de Judá forma-se quase que juntamente com o reino de Judá.

De fato, Davi se faz rei de Hebron em 958 a.C., logo depois da morte de Saul e da destruição de seu exército ${ }^{16}$. Segundo 1Sm 27,8-12; 30,26-31, Davi parece ter preparado sua volta para Judá enviando presentes aos líderes de importantes clãs do sul de Judá (DIETRICH, 2007, p. 179), articulando a formação da tribo de Judá e a sua sagração como rei de Judá em Hebron. (2Sm 2,1-4). Isto dificilmente poderia ser feito sem o consentimento dos filisteus. Os textos bíblicos informam a respeito de vários combates entre Davi e os filisteus com vitórias de Davi (1Sm 23,1-5; 2Sm 5,17-21.22-25; $8,1)$, porém, estas narrativas apresentam poucos elementos que permitam uma confirmação, e dificilmente podem ser consideradas históricas. Muito provavelmente Davi continuou sendo vassalo dos filisteus durante todo o seu reinado Hebron (DIETRICH, 2007, p. 179) e depois em Jerusalém ${ }^{17}$.

Apesar de tudo, os remanescentes da família de Saul ainda tiveram forças para juntar o que restou de seus componentes e do exército de Saul em Maanaim (2Sm 2,8-10). Maanaim situa-se na Transjordânia, na região de Jabes de Galaad, longe do alcance de Davi e dos filisteus. Isto confirma os laços desta região com a família de Saul.

16 Neste aspecto não concordamos com LIPINSKI (2018, p. 52) e com KNAUF (2016, p. 72-73). Embora com argumentos diferentes, ambos defendem que Davi formou a tribo de Judá e tornou-se rei em Hebron ainda quando Saul estava vivo. Dado que a força de Saul parece ter sido grande, a ponto de Davi ter de fugir e abrigar-se entre os filisteus, e que estes tiveram de fazer uma grande campanha militar, inclusive com apoio da guarnição egípcia estacionada em Betsã, para derrotar o exército de Saul, não nos parece possível que Davi tenha podido arrancar um pedaço do território de Saul antes dele ser vencido (ver também nota 74 abaixo).

17 KNAUF pensa em que Davi foi coroado em Hebron ainda antes da morte de Saul. E que teria havido uma divisão entre filisteus de Gat, (com Davi) e de Ekron (com Saul), considerando que a narrativa de uma vitória de Davi sobre os filisteus (de Ekron) pode ser histórica (2016, p. 72-73). LIPINSKI por sua vez considera-a uma "lenda" (legend) (2018, p. 53). 
Saul teve vários filhos com Aquinoan, sua esposa: Jônatas, Abinadab, Melquisua e Jesui, e também duas filhas: Merob e Micol (1Sm 14,49-30 e 31,2). Em Maanaim a família de Saul reaglutina-se em torno de um dos filhos de Saul, do qual não sabemos o nome certo. Jônatas, Abinadab e Melquisua morreram, juntamente com Saul, na guerra com os filisteus (1Sm 31,2). A Bíblia apresenta este quarto filho de Saul ora como nome de Isboset ( $2 \mathrm{Sm} 2,8.10 .12$; $3,8.14 .15 ; 4,5.8 .12)$, ora com o nome de Isbaal (1Cr 8,33; 9,39) e ora com o

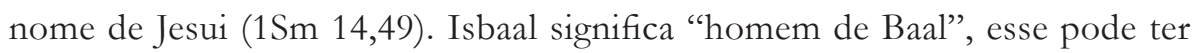
sido o nome verdadeiro deste filho de Saul, mas também pode ser mais uma das maneiras usadas pelas redações posteriores para deturparem a memória de Saul, ligando-o ao culto a Baal, uma divindade que será posteriormente execrada em Israel. O para alguns pesquisadores seu nome verdadeiro teria sido Ishyo, "homem de Javé", que na Bíblia aparece como Jesui (1Sm 14,49). Javé teria sido substituído por Baal em seu nome para difamar Saul e seu filho (DIETRICH, 2007, p. 168). Isboset significa "filho da vergonha", dificilmente algum pai ou mãe daria um nome assim para um filho. Este nome é sem dúvida fruto de redações posteriores, após a proibição do culto a Baal, quando os redatores substituíram Baal por "vergonha". Um processo semelhante deve ter acontecido com o filho de Jônatas e neto de Saul, que na Bíblia aparece como Mefibaal/Mefiboset (2Sm 4,4; 9,6-13), e como Meribaal (1Cron 8,34; 9,40).

Mas, seja como for, o restante da família e do exército de Saul continuarão organizados em Maanaim e, a partir dali tentarão rearticular o poder da casa de Saul por aproximadamente 6 ou 7 anos depois da morte de Saul (Cf. 2Sm 3,1 ${ }^{18}$. Mas não terão sucesso. Tanto o filho de Saul, que o sucedeu, como Abner o principal comandante do exército da família de Davi, serão mortos por subalternos ou aliados de Davi. Primeiro foi morto Abner (2Sm 3,6-27), e depois Isbaal/Isboset (2Sm 4,1-8). A narrativa da História da Ascensão de Davi ao Poder, no entanto inocenta Davi destes assassinatos. Em 2Sm 3,28-39 Davi é inocentado da morte de Abner. E em 2Sm 4,9-12 é inocentado da morte de Isboset ${ }^{19}$.

18 1Sm 2,10 afirma que Isbaal reinou somente dois anos. Porém, o tempo de duração do reinado de Isbaal pode ter sido adulterado da mesma forma que foi adulterado o tempo de

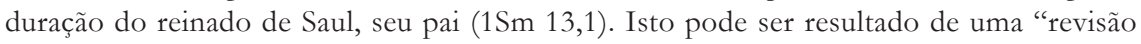
maliciosa" posterior (LIPINSKI, 2018, p. 51) que visava diminuir a importância de Saul e de engrandecer a figura de Davi.

19 Interessante é que a "História da ascensão de Davi ao trono" inocenta-o da morte de seus inimigos. E a "História da Sucessão de Davi", ou da ascensão de Salomão ao trono, irá atribuir a Davi a culpa pela morte de seu aliado Joab (1Rs 2,1-6). 
A narrativa bíblica mostra Davi tomando todos os cuidados para eliminar ou controlar todos os remanescentes da casa de Saul que pudessem reclamar seus direitos sucessórios. Assim Davi mandará buscar Mefiboset, filho de Jônatas, neto de Saul, e o manterá dentro das muralhas de Jerusalém (2Sm 9,1-3). Fez com Mefiboset o mesmo que já havia feito com Micol, a filha de Saul, colocou ambos dentro das muralhas de Jerusalém, onde pudessem ser vigiados e controlados. Uma espécie de "prisão domiciliar". Pior sorte terão os filhos que Saul teve com sua concubina chamada Resfa, e também os filhos que Micol havia tido com outro marido. Todos foram entregues aos gabaonitas, antigos inimigos de Saul, que os massacraram (2Sm 21,1-10). Assim, por volta dos anos 952-951 a.C., termina o reino Benjaminita da casa de Saul. Davi consolida sua posição entrando em Jerusalém, e com isso a casa de Saul definhará e praticamente desaparecerá.

Semei, um membro influente da casa de Saul, que de acordo com os relatos bíblicos consegue reunir "mil homens", será ainda citado algumas vezes (2Sm 16,5-8; 19,17-310. Mas, as tribos do norte, Efraim e Manassés ficarão por aproximadamente duas décadas, sem uma organização política e militar eficiente. É possível que durante esses anos de desorganização a região tenha sofrido incursões e domínio de Filisteus, de egípcios baseados em Betsã, e até mesmo de Davi. O certo é que existiram tentativas de resistência e rearticulação como as revoltas de Absalão (2Sm 15-18) e Seba (2Sm 20), mas serão derrotadas. Estas tribos só conseguiram se reorganizar, ao redor dos anos 927 a.C. com Jeroboão I, na "entidade territorial norte israelita ao redor de Siquém - Tersa” (FINKELSTEIN, 2015b, p. 30), em Efraim.

\section{Observação final}

O caminho adotado neste artigo, após considerar e analisar o que é afirmado pela maioria dos pesquisadores a respeito do antigo Israel - no estudo crítico da Bíblia e na arqueologia - foi o de adaptar a cronologia apresentada para Saul, Davi, Salomão, Roboão e Jeroboão I por Edward LIPINSKI (2018, p. 49-63). Com o objetivo de apresentar uma possível sequência dos acontecimentos nos inícios dos reinos de Israel e de Judá, numa narrativa que seja coerente com os dados arqueológicos e informações históricas presentes nas camadas pré-deuteronomistas das narrativas bíblicas (cf. GRABE, 2007, p. 121).

Como é possível ser mais seguro no estabelecimento da datação de Jeroboão I, que governou mais ou menos entre 927-905 a.C., e dos reis 
seguintes, é aceitável apoiar-se na ordem e na cronologia que a Bíblia nos apresenta. Sobre isto, até mesmo Israel Finkelstein, um dos representantes da nova arqueologia, afirma:

Não vejo razão para duvidar dos nomes, ordem e datas desses reis. A ordem dos monarcas israelitas e judaítas, com a duração de reinado e informações cruzadas entre os dois reinos, é sustentada pela menção de alguns deles em textos extra bíblicos. [...] Também a exata duração dos reinados para esses e outros reis parece confiável, na medida em que são diferentes dos 40 anos cada, dados a Davi e Salomão fundadores da dinastia davídica. O último é um número tipológico, significando não mais que 'muito tempo', ou 'muitos anos'. Isso significa que o antigo historiador deuteronomista do final do século VII a.C. tinha acesso a um registro dos reis israelitas e judaítas (FINKELSTEIN. 2015 p. 86-87. Também KNAUF, 2016, p. 67).

Assim sendo, a partir da proposta de reconstrução da história de Saul, apresentada ao longo do artigo, é talvez mais acertado manter a informação bíblica, de que Saul teria sido morto por filisteus, possivelmente de Gat, uns 20 anos antes da campanha de Sheshonq I. Os escritores Deuteronomistas convenientemente afirmam que Sheshonq invadiu Judá. Lhes serve para explicar por que não se encontravam em Jerusalém as imensas riquezas que atribuíram ao reinado de Salomão (KNAUF; GUILLAUME, 2016, p. 82). No entanto o ataque de Sheshonq I a Jerusalém não é confirmado pelos dados arqueológicos. Uma longa lista de localidades contendo entre 150 (MILLER; HAYES, 2006, p. 262) e 180 nomes de localidades (LIVERANI, 2008, p. 137) atravessadas, conquistadas, ou eventualmente destruídas por Sheshonq I, é fornecida nas paredes do Templo de Karnak, dedicado ao Deus Amun. Esta lista, entretanto, "não inclui as planícies e regiões montanhosas de Israel [...] Jerusalém e a totalidade das terras altas da Judeia [...] nenhuma cidade judaíta da Shefelá (FINKELSTEIN, 2015, p. 63)". Isso pode ser um indício de que Judá manteve-se como vassalo, ou aliado, dos filisteus, que por sua vez eram vassalos aliados do Egito. Certamente por isso também a lista "não menciona as cidades filisteias (GRABE, 2007, p. 82)". Lester Grabe afirma que os locais listados podem mesclar locais atacados com locais que eram amigos, aliados, que logicamente não foram atacados (2007, p. 82). As localidades aliadas encontravam-se no caminho para a Palestina, e possivelmente foram visitadas para arregimentar contingentes de guerreiros destas localidades.

Por outro a lista das cidades atacadas por Sheshonq apresenta especialmente lugares localizados ao norte de Jerusalém, como Gabaon, Bet 
Horon, Samaria, cidades no vale do Jaboc, a leste do rio Jordão, como Sucot, Fanuel, Maanaim, e alcançou o vale de Jezrael, citando "Meguido, Taanac, Rehov, Bet Shean [...], lugares aos quais os egípcios nunca haviam dirigido uma campanha militar (FINKELSTEIM, 2015, p. 63-64). Combinando estes argumentos, é claro que o monarca egípcio dirigiu sua campanha ao "vale de Jezrael, no início do Ferro IIA" (FINKELSTEIN, 2015, p. 100). E este é exatamente o território atribuído ao domínio da entidade política israelita baseada em Tersa-Siquém e governada por Jeroboão I. O texto de 1 Reis 12,25 diz que Jeroboão fortificou Penuel, na transjordânia, região onde teria acontecido a coroação de Ishbaal (2Sm 2,8-9), com isto Jeroboão buscava certamente "o controle sobre o acesso aos depósitos de ferro de Ajlun (KNAUF; GUILLAUME, 2016, p. 81).

A relação de Jeroboão e Sisac (Sheshonq), encontra-se mais elaborada na Septuaginta, que pode ter-se originado de uma fonte mais antiga, pré-deuteronomista, semelhante à narrativa dos juízes libertadores (FINKELSTEIN, 2015, p. 104). E foi possivelmente o objetivo de retomar o controle sobre o vale de Jezrael e sobre o acesso às minas de Ajlun ${ }^{20}$ que motivou a campanha de Sheshonq I. Tudo isso, no entanto, são temas para outras pesquisas e artigos.

\section{Referências}

ANDERSON, J. S. Monotheism and Yahweh's appropriation of Baal. London: T\&T Clark, 2015.

BADEN, J. Davi. A vida real de um herói bíblico. Rio de Janeiro: Zahar, 2016.

BIRAN, A.; NAVEH, J. An Aramaic Stele Fragment from Tel Dan. Israel Exploration Journal, Vol. 43, No. 2/3, pp. 81-98, 1993.

CARR, D.M. The formation of the Hebrew Bible. A new reconstruction. New York: Oxford University Press, 2011.

CLINE, E. H. Biblical Archaeology: A Very Short Introduction. New York: Oxford University Press, 2009.

DAY, J. Yahweh and the gods and goddesses of Canaan. London: Sheffield Academic Press, 2000.

20 Os depósitos de ferro de Ajlun eram excepcionalmente ricos e aparentemente foram exploradas durante a Idade do ferro. Os mais antigos objetos de ferro (braceletes e/ou tornozeleiras) foram encontrados em Tell Hammeh, 3 ou $4 \mathrm{Km}$ a sudoeste dos depósitos (ver YAHALON MACK, 2017, p. 452). 
DEVER, W. G. What Did the Biblical Writers Know and When Did They Know It? What Archeology Can Tell Us About the Reality of Ancient Israel. Grand Rapids, Michigan/ Cambridge, U.K.: Eerdmans Publishing, 2001.

DEVER, W. G. Beyond the texts. An archaeological portrait of ancient Israel and Judah. Atlanta: SBL press, 2017.

DIETRICH, L. J. O processo e a função social da produção da imagem de Davi como pastor que fala em nome de Yhwh zebaot, em 1 Samuel 17.1-18,5. 2002. 286 p. Universidade Metodista de São Paulo. São Bernardo do Campo. São Paulo.

DIETRICH, W. The early monarchy in Israel. The tenth century B.C.E. (Biblical Encyclopedia/Biblische Enziclopädie, vol. 3) Atlanta: Society of Biblical Literature, 2007.

DONNER, H. História de Israel e dos povos vizinhos. São Leopoldo/Petrópolis: Sinodal/ Vozes, Volume 1, 2 ${ }^{\mathrm{a}}$ ed., 2000.

DREHER, C. A. A constituição dos exércitos no reino de Israel. São Leopoldo/São Paulo: CEBI/Paulinas, 2002.

FAUST, A. From regional power to peaceful neighbour. Philistia in the Iron I-II transition. Israel Exploration Journal, v. 63, p. 154-173. 2013.

FAUST, A. Proof of King David? Not yet. But riveting site shores up roots of Israelite era. In: The Times of Israel. 14 May 2018.( https://www.timesofisrael.com/proof-of-king-davidnot-yet-but-riveting-site-shores-up-roots-of-israelite-era/, acessado em 20 de janeiro de 2020.

FINKELSTEIN, I.; SILBERMAN, N. A. A Bíblia não tinha razão. São Paulo: A Girafa Editora, 2003. (The Bible Unearthed: Archaeology's New Vision of Ancient Israel and the Origin of its Sacred Texts, de 2001, da qual foi traduzida esta oba, após ficar ausente das livrarias por vários anos, recebeu uma nova tradução para o português, mais esmerada e bem mais competente realizada por Nélio Schneider, e foi republicada com o título: A Bíblia desenterrada. A nova visão arqueológica do antigo Israel e das origens dos seus textos sagrados. Petrópolis: Vozes, 2018.)

FINKELSTEIN, I. Is the Philistine paradigm still viable? In: BIETAK, M.; CZERNY, E. (Eds.) The synchronization of civilisations in the Eastern Mediterranean in the Second Millennium B.C. Vienna: Austrian Academy of Sciences Press, 2007, p. 517-523.

FINKELSTEIN, I; PIASETZKY, E. The Iron Age chronology debate: Is the gap narrowing? Near Eastern Archaeology, v. 74, p. 50-54, 2011.

FINKELSTEIN, I. The forgotten Kingdom. The archaeology and history of northern Israel. Atlanta: Society of Biblical Literature, 2013.

FINKELSTEIN, I. O reino esquecido. Arqueologia e história de Israel Norte. São Paulo: Paulus, 2015.

FINKELSTEIN, Israel. Saul, Benjamim e o surgimento do "Israel Bíblico": uma visão alternativa. Caminhando, v. 20, n. 2, p. 23-43, jul./dez. 2015b.

GOTTWALD, N. K. As tribos de Iahweh. Uma sociologia da religião de Israel liberto. São Paulo: Paulinas, 1986. 
GRABBE, L. Ancient Israel: What do we know and how do we know it? London/New York: T\&T Clark, 2007.

HALPERN, B. David's Secrets Demons. Messiah, murderer, traitor, king. Grand Rapids, Michigan: Wm. B. Eerdmans Publishing, 2001.

HALPERN, B. The United monarchy. David between Saul and Salomon. In: EBELING, J.; WRIGHT, J. E.; ELLIOT, M.; FLESHER, P. V. M. The Old Testament in Archaeology and History. Waco, Texas: Baylor University Press, 2017, p. 337-362.

HALPERN, B. The United monarchy. In: EBELING, Jennie; WRIGHT, J. Edward; ELLIOT, Mark; FLESCHER, Paul M. (Editors), The Old Testament in archaeology and history. Waco, Texas: Baylor University Press, 2017, p. 337-362.

KAEFER, J. A. A Bíblia, a Arqueologia e a História. In: CARNEIRO, M. (org.), Bíblia e Cultura: Tradição, Tradução e Exegese - Debatendo as diferentes leituras da Bíblia. São Paulo: Fonte editorial - ABIB, 2014, p. 149-166.

KAEFER, J. A. A estela de Dã. Caminhando, v. 17, n. 2, p. 33-46, 2012.

KAEFER, J. A. O Êxodo como tradição de Israel Norte, sob a condução de El e Javé na forma de touro jovem. Horizonte, v. 13, n. 38, p. 878-906, abr./jun. 2015.

KAEFER, J. A. A Bíblia, a arqueologia e a história de Israel e Judá. São Paulo: Paulus, 2015b.

KAEFER, J. A. À procura de Saul! Uma análise de Primeiro Samuel 9-(12)14. Horizonte, v. 14, n. 42, p. 402-426, abr./jun. 2016.

KNAUF, E. A.; GUILlAUME, P. A History of Biblical Israel. The fate of the kingdoms from Merenptah to Bar Kochba. Sheffield, U.K./Bristol: Equinox, 2016.

KOCH, I. Early Philistia revisited and revised. In: LIPSCHITS, O.; GADOT, Y.; ADAMS, M. (Eds.) Rethinking Israel. Studies in the history and archaeology of ancient Israel in honor of Israel Finkelstein. Winona Lake, Indiana: Eisenbrauns, 2017, p. 189-205.

LEMCHE, N. P. The Israelites in History and Tradition. London/Louisville: SPCK/ Westminster John Knox Press, 1998.

MAEIR, A. M.; HITCHKOCK, L. A. Rethinking the philistines. In: LIPSCHITS, O.; GADOT, Y.; ADAMS, M. (Eds.) Rethinking Israel. Studies in the history and archaeology of ancient Israel in honor of Israel Finkelstein. Winona Lake, Indiana: Eisenbrauns, 2017, p. 247-266.

LIPINSKI, E. A History of the Kingdom of Israel. (Orietalia Lovaniensia Analecta, 275), Leuven/Paris/Bristol: Peeters, 2018.

LIVERANI, M. Para além da Bíblia. História antiga de Israel. São Paulo: Paulus/Loyola, 2008.

MAZAR, A. Arqueologia na terra da Bíblia. 10.000 - 586 a.C. São Paulo: Paulinas, 2003.

MAZAR, A. Tel Beth-Shean: History and Archaeology. In: KRATZ, R.G.; SPIECKERMANN, H.; CORZILIUS, B.; PILGER, T. (Editors). One God - One cult - One Nation. Archaeological and Biblical Perspectives. Berlin/New York: BZAW, 2010, p. 239-272. 
MILLER, J. M.; HAYES, J. H. A history of ancient Israel and Judah. Louisville/London: Westminster John Knox Press, $2^{\mathrm{a}}$ ed., 2006.

OROFINO, F. R. 1 Sm 25,1-44 Davi, Nabal e Abigail. A aliança entre Davi e os clãs de Judá. In: DietriCH, L. J.; NAKANOSE, S.; OROFINO, F. R. Primeiro Livro de Samuel. Pedir um rei foi nosso maior pecado. Petrópolis/São Leopoldo: Vozes/Sinodal, 1999, p. 269-278.

PROVAN, I.; LONG, V. P.; LONGMAN III, T. Uma história bíblica de Israel. São Paulo: Vida Nova, 2016 (original de 2003).

REIMER, H. Da diversidade à singularidade. In: REIMER, H. Inefável e sem forma. Estudos sobre o monoteísmo hebraico. São Leopoldo/Goiânia: Oikos/Editora da UCG, 2009, p. 21-52.

REIMER, H. O Antigo Israel. História, textos e representações. São Paulo/Anápolis: Fonte Editorial/Editora da Universidade Estadual de Goiás, 2017.

SCHNIEDEWIND, W. S. Como a Bíblia tornou-se um livro. São Paulo: Loyola, 2011.

SCHWANTES, M. História de Israel. Local e origens. São Leopoldo: EST (mimeografado), 1984.

SKA, J-L. Tendências fundamentais na pesquisa do Pentateuco nos últimos dez anos. In: CARneiro, M. da S.; OTTERMAnN, M.; Figueiredo, T. J. A. de. Pentateuco: da formação à recepção. Contribuições ao VII Congresso da ABIB. São Paulo, SP: Paulinas/ ABIB, 2016, p. 13-87.

SMITH, M. S. The early history of God. San Francisco: Harper \& Row, 1999.

YAHALOM-MACK, N. Metal production and trade at the turn of the first millennium BCE. In: LIPSCHITS, O.; GADOT, Y.; ADAMS, M. (Eds.) Rethinking Israel. Studies in the history and archaeology of ancient Israel in honor of Israel Finkelstein. Winona Lake, Indiana: Eisenbrauns, 2017, p. 251-261.

ZABATIERO, J. P. T. Uma história cultural de Israel. São Paulo: Paulus, 2013.

Submetido em: 3-1-2020

Aceito em: 28-5-2020 